Meyrick's "Handbook" (1928), although it is a true Heliophobus. I do not hesitate to assert that this is by no means an isolated case among the British moths.

In the first edition of the "Handbook" (1895) appeared the dicta which have been called "Meyrick's Law" : (1) No new organ can be produced except as a modification of some previously existing structure. (2) A lost organ cannot be regained. (3) A rudimentary organ is rarely redeveloped. It strikes me as strange that Meyrick should have reprinted these statements without modification after thirty-two years. One would have preferred the following modifications: (2) A lost organ is not regained. (3) A vestigal organ is rarely redeveloped.

In 1912 Meyrick commenced a separate publication of his own which he called Exotic Microlepidoptera and described as "a spasmodic entomological magazine on one subject by a single contributor". In his original preface Meyrick wrote :

"The purpose of this volume is to ensure the speedy publication of material which is required for immediate use in other works proceeding at the same time, especially in my contributions to the Genera Insectorum and Lepidopterorum Catalogus; the delays incidental to publication through other channels would otherwise involve so much arrangement in advance as to seriously hamper the work."

Up to September, 1936, four volumes had been completed, running to some 2,500 pages in all, and during the next twelve months 160 pages of vol. 5 had appeared.

Latterly, Meyrick collaborated with Prince Aristide Caradja, the distinguished Roumanian lepidopterist, in a number of important papers on the Palæarctic Microlepidoptera (including Pyralidæ), with some valuable contributions to our knowledge of the Chinese fauna.

For many years Meyrick had identified Microlepidoptera and Pyralidæ for the Imperial Institute of Entomology. He was a very quick worker, a delightful correspondent and he rarely kept a colleague waiting long for identifications, always describing at once any new species.

I was pleased to note the impression made upon Meytick, who was a man of very conservative views, by Wegener's theory of continental drift, even before the more recently collected evidence in support of it had been brought forward.

Meyrick was elected a fellow of the Royal Society in 1904. He had been a fellow of the Royal Entomological Society of London since 1880.

It is gratifying to learn that Mr. Meyrick's extensive collection, the value and importance of which it is impossible to estimate, is bequeathed to the British Museum (Natural History).

W. H. T. TAMs.

An anthropological correspondent writes :

For many years Mr. Meyrick was responsible for the records of anthropometric measurement of the Marlborough boys, on which he prepared the reports appearing in the publications of the Marlborough
College Field Club. When the Inter-Departmental Committee on Physical Deterioration, which reported in 1904, was sitting, the lack of exact evidence relating to the trend of physical development in the child and adolescent population of Great Britain was a grave drawback; but the Marlborough records, being almost the only material available for comparative purposes extending over any considerable period of time, afforded information of the greatest value for the inquiries of the Committee. It was mainly on this material that the Committee based its finding that the public school population, at least, showed no evidence of the alleged physical deterioration in the population at large, into which the Committee was appointed to inquire. The absence of exact data respecting the physical development of the school population of England and Wales was one of the decisive factors in bringing about the passing of the Act of 1907 for the medical inspection of school children; though much to the disappointment of many who were among its strongest supporters, it was not considered practicable to introduce into the elementary school a scheme of anthropometric measurement of a more extended character.

\section{Dr. G. B. Grinnell}

THE death is reported of Dr. George Bird Grinnell, distinguished as geologist, naturalist and ethnologist, which took place in New York on April 11 at the age of eighty-nine years.

Dr. Grinnell was born on September 20, 1849, and educated at Yale University, where he graduated in 1870 , proceeding to the degree of $\mathrm{Ph} . \mathrm{D}$. in 1880 , and being awarded the D.Litt. in 1921. In 1870 he began his study of the Plains Indians, one of the activities for which he became most widely known. He was long recognized as the foremost authority on the history and customs of the Blackfeet, Pawnee and other Plains Indians, so that his appointment as Special Commissioner for the sale of lands to the Blackfeet and Fort Belknap Indians in 1895 was natural, and indeed inevitable. From 1874, when he joined the staff of the Peabody Museum as assistant osteologist, until his retirement in 1911, he was attached to this Museum or to the staff of Yale University. $\mathrm{He}$ was extremely active in collecting fossils and other specimens for the Museum, and took part in several expeditions, among them that to the Black Hills in 1874, the Yellowstone Park Reconnaissance expedition in 1875, expeditions to the Plains and the Rocky Mountains on behalf of his Museum, and the Harriman expedition to Alaska in 1899. Grinnell was the first in America to take action against the wholesale destruction of wild fowl and game, and his love for wild life in all its forms led to the foundation of the Audubon Society. For some years he was chairman of the Council on National Parks, Forests and Wild Life, and in 1925 succeeded President Hoover as president of the National Parks Association. In the same year he was awarded the Roosevelt Distinguished Service Medal for his lifetime's devotion to outdoor life. 